* Doutorando em Sociologia e Direito pela Universidade Federal Fluminense. Mestre em direito pela Universidade Estadual de Maringá.

** Graduado em Direito.

\section{LIMITES ONTOGNOSEOLÓGICOS \\ PARA A TUTELA JURÍDICO-PENAL DO AMBIENTE NO BRASIL}

\author{
ONTOGNOSEOLOGIC LIMITS IN THE \\ ENVIRONMENTAL PROTECTION WITH \\ THE USE CRIMINAL LAW IN BRAZIL
}

\section{Cláudio Ribeiro Lopes* Kleber Henrique Facchin**}

Como citar: LOPES, Cláudio Ribeiro. FACCHIN, Kleber Henrique. Limites ontognoseológicos para a tutela jurídico-penal do ambiente no Brasil. Revista do Direito Público, Londrina, v. 11, n. 2, p.260-288, ago. 2016. DOI: $10.5433 / 1980-511 X .2016 v 11 \mathrm{n} 2 \mathrm{p} 260$. ISSN: $1980-511 \mathrm{X}$.

RESUMO: Desde a Sociologia Conflitiva, muitos tem sido os desafios enfrentados pelo ambiente até alcançar a relevância jurídico-social que tem atualmente. Nesse longo e tortuoso percurso, o ambiente já fora guarnecido por normas que visavam à proteção da propriedade privada, por outras sem qualquer preocupação com a degradação ambiental em si e, até mesmo, pelas que miravam à gestão dos recursos naturais, cujos fins eram meramente administrativos. Atualmente, a tutela-jurídica do ambiente alçou maior autonomia, inclusive na área penal, frente a seu reconhecimento constitucional como bem indispensável às presentes e futuras gerações. Diante disso, é preciso buscar conhecer efetivamente o 
cerne da proteção do ambiente pelo Direito Penal e a via pela qual se pretende desvendar isso neste trabalho é a ontognoseologia, aplicando-a, inclusive, ao estuda da pena, principal consequência jurídica do delito.

Palavras-chave: Ambiente. Teorias do delito. Ontognoseologia. Fins da pena. Proteção jurídica.

ABSTRACT: Ever since Conflict Sociology, the environment has faced many challenges in achieving its current legal and social relevance. Throughout this long and tortuous route, laws that aim for the protection of private property have affected the environment; thus, most of them do not even care for its degradation and have even influenced the management of natural resources - whose purposes were only administrative. Currently, the environment has greater legal protection - including in criminal law, which has its inner workings based on the Federal Constitution -, more autonomy, and is indispensable for present and future generations. Therefore, the search for effective environmental protection with criminal law is a means in which this paper will problematize ontolognoseology, incidentally applying these concepts to the understanding of the penalty, which, in a way, is the most important legal consequence of crimes.

Key-words: Environment. Criminal theories. Ontognoseology. Ends of criminal penalties. Legal protection. 


\section{O SER SOCIAL E A SOCIOLOGIA CONFLITIVA}

O ser humano é um animal inexoravelmente social. Ao longo dos tempos e das gerações, essa característica aderiu à natureza humana de tal forma que hodiernamente é não apenas necessário, mas, inerente ao ser humano viver em sociedade.

Há que se salientar, também, o proeminente desenvolvimento do aparato cerebral do homo sapiens, o que possibilita a formação de identidades complexas no aparelho psíquico - propriamente aquilo que a psicanálise identifica como ego ${ }^{1}$-, com conceitos e opiniões que não são necessariamente - e tendentemente não serão - comuns à coletividade ${ }^{2}$.

Assim, os seres humanos encontram na agregação organizada o meio ideal de sobrevivência e perpetuação da espécie. Contudo, as sociedades humanas se distinguem pelo agrupamento de indivíduos extremamente complexos e, por isso mesmo, diferentes entre si.

Destarte, e considerando que a capacidade de comunicar-se e praticar a diplomacia não se mostra suficiente para harmonizar os interesses particulares com os coletivos, a humanidade jaz repleta de conflitos e tensões que se tornam inerentes à vida social a tal ponto que, no decorrer da História, as sociedades humanas empreenderam inúmeros esforços a fim de conceber mecanismos capazes de dirimir os conflitos sociais e restabelecer o bem estar e a paz social, sendo que, nem sempre se logrou isso sem elevados custos humanos.

Usualmente, classificam-se três meios possíveis de eliminação de conflitos. O mais primitivo contempla o direito de cada indivíduo defender pessoalmente seus próprios interesses. Conhecido como auto-

1 Formado pelo conhecimento acumulado de si e do mundo circundante.

2 Porquanto, a algum grupo social específico, dentre uma gama de diversos grupos sociais distintos entre si. 
defesa ou auto-tutela, esse método permite que cada sujeito combata por si, em nome de seus interesses, o que implica na imposição do interesse de um indivíduo - invariavelmente a parte mais forte - em prejuízo do interesse de outro (CINTRA; GRINOVER; DINAMARCO, 2006, p. 26).

Entende-se necessário destacar uma possível distinção entre $o$ que venha a ser autodefesa e autotutela. Pela simples análise terminológica de um e de outro, é possível inferir que embora ambos indiquem que o indivíduo tem autorização para cuidar de si mesmo, a autodefesa remete a um entendimento mais passivo, com escopo ao repúdio de um ataque, enquanto o termo autotutela permite um entendimento mais amplo de tutela pessoal.

Acompanhando este raciocínio, é possível observar que o direito à auto-defesa coube, desde os tempos mais remotos, a todo membro de uma comunidade humana, porém, em hipóteses similares às que a autorizam até hoje, quais sejam, basicamente, a legítima defesa e o estado de necessidade ${ }^{3}$.

Quanto à auto-tutela, nota-se que a partir do momento em que os grupos humanos desenvolveram um mínimo de civilidade, esta forma de resolução de conflitos - alcunhada como o direito de fazer justiça com as próprias mãos - fora repudiada pelas sociedades, tornando-se exceção ${ }^{4}$, superveniente sobretudo nos adventos alienígenas à convenção de convívio social como a clandestinidade, a criminalidade ou a guerra ${ }^{5}$.

Nesse sentido, recentes estudos abalizam que já nos antigos clãs a aplicação de punições contemplava o interesse coletivo e não o pessoal. Naquela época, mais propriamente a fim de conservar o clã sob

3 Bem como - observada a consolidação do Estado de Direito - o exercício regular de direito e o estrito cumprimento do dever legal.

4 Exceção observada somente na sociedade, não na lei, que proíbe qualquer hipótese de justiça privada.

5 Frise-se que tal análise é antropológica, não se falando em licitude ou ilicitude. 
a proteção de divindades e afastar a sua ira, haja vista que "o homem primitivo acreditava que os seres sobrenaturais castigavam ou premiavam a sociedade de acordo com o seu comportamento" (SHECAIRA; CORRÊA JUNIOR, 2002, p. 24).

Como se vê, toda sociedade, em seu processo de formação, observou algum tipo de freio ético-social, quer fundado em preceitos religiosos, seja em normas cunhadas pelo homem para programar a conduta social dos membros da coletividade.

Enfim, a segunda hipótese de solução de conflitos, chamada autocomposição. Esta, por sua vez, caracteriza-se por uma espécie de acordo entre os conflitantes, no qual as partes podem consentir pelo sacrifício total ou parcial do próprio interesse, chegando a uma medida que satisfaça a ambas (CINTRA; GRINOVER; DINAMARCO, 2006, p. 26). Ao que tudo indica, essa alternativa fora utilizada em todos os modelos sociais, encontrando espaço até os dias de hoje, sobretudo nos grupos sociais menos urbanos. Quanto mais pessoas aglomeradas em um núcleo social, mais complicada se torna a aplicação desta alternativa ${ }^{6}$, de sorte que hodiernamente o Poder Judiciário promove constantes campanhas pela adoção de modos alternativos de composição, como a arbitragem, a mediação e a conciliação.

É flagrante, todavia, que tanto a autodefesa como a autotutela padecem de problemas essenciais, haja vista que, tendentemente, a parte mais forte não consentirá pelo sacrifício de seus interesses, na medida em que possa impor sua vontade em detrimento da parte mais fraca ${ }^{7}$.

Com a instabilidade desses modelos, ganhou relevância política

6 E mais rara, na medida em que emergirão meios próprios para julgar conflitos de interesses.

7 Supondo a ausência de um terceiro responsável por evitar qualquer tipo de vício na composição, como o mediador, conciliador ou árbitro, que na autocomposição contemporânea, promovida pelo próprio Estado, é sempre exigida para a legitimidade dos acordos. 
o modelo pelo qual as pessoas em sociedade elegem para si uma liderança para mediar as relações conflituosas, governar o grupo e tomar decisões em nome da coletividade. Nesse contexto, ascende a terceira via de extinção dos conflitos sociais, denominada heterocomposição. Esta forma de solução de conflitos preconiza a intervenção de um terceiro, seja uma autoridade estabelecida pela confiança dos próprios sujeitos conflitantes ou previamente constituída pela coletividade, com competência e capacidade para julgar segundo as normas pré-postas.

De princípio, esta intervenção própria do método heterocompositivo era confiada aos sacerdotes, que tinham a prerrogativa de julgar de acordo com a vontade divina, ou aos anciãos, que tinham o respeito do grupo e bem conheciam seus costumes (CINTRA; GRINOVER, DINAMARCO, 2006, p. 27).

Nos dias de hoje, o Estado possui um arcabouço sistêmico próprio para o julgamento de todo tipo de crise social emergente na circunscrição estatal. Tendo instituído o monopólio sobre o direito de julgar todo conflito e todo desvio da conduta determinados pelas normas estatais, o Estado-Juiz se obriga a apreciar e oferecer soluções de justiça para os conflitos sociais, operando como efetivo tutor dos direitos subjetivos.

\section{O JUS PUNIENDI E A TUTELA JURÍDICO-PENAL PELO ESTADO}

Ao longo dos tempos, a tutela jurídico-penal assumiu diferentes formas, em consonância com o modelo de Estado, a forma de governo e a organização social, alcançando contornos cada vez mais centralizadores.

Por volta do século III d.C., os pretores romanos alçaram 
competência para pessoalmente julgarem e proferirem as sentenças, sem a necessidade de nomear um árbitro. A partir de então, o Estado "impõese sobre os particulares, prescindindo da voluntária submissão destes" (CINTRA; GRINOVER. DINAMARCO, 2006, p. 29), estabelecendo definitivamente seu monopólio sobre a função jurisdicional, abarcando inclusive a exclusividade sobre o direito de infligir uma sanção àquele que, sob sua jurisdição, transgrida uma norma penal ${ }^{8}$.

Hodiernamente, a autoridade de punir se concentra no Estado desde a produção das normas de conduta ${ }^{9}$ até a aplicação das sanções aos seus transgressores ${ }^{10}$. Contudo, a partir do momento em que avoca para si o monopólio do direito de punir - o jus puniendi -, por conseguinte, o órgão estatal assume o dever pela tutela de bens jurídicos relevantes para a coletividade (CORRÊA JÚNIOR; SHECAIRA, 2002, p. 124-5). Destarte, o jus puniendi apresenta-se como um imperativo ao Estado ${ }^{11}$ que se incumbe de vigiar e punir.

Sobretudo, considerando que tutela significa proteção, a tutela jurídico-penal pelo Estado constitui um direito da sociedade à proteção estatal. Nesse sentido, a Constituição Federal de 1988 trouxe uma série de normas que designam deveres à República Federativa do Brasil, dentre os quais adere ao foco do presente trabalho o disposto no artigo 225:

\section{Todos têm direito ao meio ambiente ecologicamente equilibrado, bem como de uso}

\footnotetext{
8 Que não precisa estar obrigatoriamente consolidada numa codificação. Entende-se por "lei penal" toda norma estatal que prescreva - ainda que segundo costumes - uma sanção como retribuição negativa a certa conduta repudiada pela sociedade.

9 Embora a criação legislativa seja condicionada à norma constitucional, abrangendo os direitos fundamentais da pessoa humana, os direitos sociais e todo poder conquistado pelos movimentos sociais em face do Estado.

10Note-se que em observância à divisão dos poderes, cada uma destas atribuições cabe a autoridades diferentes.

$11 \mathrm{Na}$ verdade, independente da natureza jurídica - se penal, cível, etc. -, a tutela jurisdicional se apresenta, além de direito exclusivo do Estado, também como incumbência ao Estado.
} 
comum do povo e essencial à sadia qualidade de vida, impondo-se ao Poder Público e à coletividade o dever de defendê-lo e preservá-lo para as presentes e futuras gerações. (BRASIL, 1988, p.98).

Destarte, cabe ao Estado tomar as providências necessárias para proteger o ambiente e, nesse sentido, adiante no referido dispositivo constitucional, mais especificamente em seu o parágrafo primeiro, consta um rol de incumbências concretas ao Poder Público, rumo à efetivação do propósito expresso no caput - incluindo a criação de legislação.

Vale salientar que mesmo antes da Constituição denominada cidadã $^{12}$, o Estado brasileiro já havia editado diversas leis ambientais ${ }^{13}$ que ofereciam considerável proteção ao ambiente. No entanto, o fato de que as leis estavam fragmentadas induzia grande dificuldade para o conhecimento universal da vetusta legislação ambiental, calhando em incongruências e lacunas e, por conseguinte, na fragilização da tutela jurídica do ambiente àquela época (PRADO, 1992, p. 38).

Ainda, aliada à fragmentariedade da legislação ordinária, a ausência de uma norma superior e disposições políticas efetivamente voltadas para a proteção ambiental, assim como a intensa inclinação desenvolvimentista dos dirigentes políticos responsáveis pela fiscalização e aplicação das leis, relegou à inépcia os instrumentos jurídicos de proteção ambiental até então existentes.

Após a promulgação da atual Constituição Federal, que vem embarcada na tendência de preservação ambiental iniciada em Estocolmo

12Antonomásia atribuída por Ulysses Guimarães à Constituição Federal promulgada em 1988.

13Como, por exemplo, o Código de Águas (1934), o Código Florestal (1965), a Lei de Proteção à Fauna (1967) e, pós-Estocolmo, a PNAMA - Política Nacional do Meio Ambiente (1981). 
$(1972)^{14}$, as leis ambientais ganham maior desponte no ordenamento jurídico nacional, com o surgimento de novas leis e programas de proteção e conscientização, tais como a Lei dos Agrotóxicos, a Lei de Biossegurança (2005) ${ }^{15}$, a Política Nacional de Educação Ambiental (1999), e, também, a Lei n. 9.605, de 12 de fevereiro de $1998^{16}$, que explicita os delitos ambientais e as penas aplicáveis.

Não obstante a sua subsidiariedade, o envolvimento do Direito Penal na seara ambiental representou um passo bastante relevante na direção de se tentar garantir o respeito aos limites impostos à degradação ambiental e, desta forma, repudiar a dilapidação do bem jurídico ambiental.

É sabido que, impelido pelos ímpetos de adaptação ${ }^{17}$ e de acumulação inerentes à humanidade, o progresso tecnológico estabeleceu um processo contínuo e irreversível de exploração dos recursos naturais. Todavia, ocorre que as atividades concernentes ao desenvolvimento tem consequências igualmente irreversíveis, de tal sorte que a trilha da civilização revela a paulatina substituição da natureza pelo produto do trabalho humano, muita vez, com menoscabo considerável para o ambiente natural.

Ademais, mormente a partir das últimas décadas do século XX, houve uma explosão da pesquisa tecnológica no mundo, elevando a níveis cada vez mais céleres o crescimento industrial e o desenvolvimento urbano. Nesse contexto, o ambiente fora submetido a uma avassaladora ação predatória, lesado tanto pela desenfreada extração de recursos da

14Cuja onda de conscientização já havia motivado em 1981 a edição da Política Nacional do Meio Ambiente (PNAMA).

15 As quais traziam em seu bojo infrações e sanções inclusive de caráter penal.

16Cuja promulgação revogou as penas previstas nos antigos Código Florestal (1965) e Código de Caça (1967).

17 Não para adaptar-se ao meio, mas para adaptar o meio a si. 
natureza quanto pela crescente devastação de espaços naturais para dar lugar a áreas agricultáveis, à pecuária e à urbanização.

Some-se a isso o problema acentuado pelo consórcio entre defensivos agrícolas e sementes/mudas transgênicas, como é o caso da soja, do milho e do eucalipto e outras commodities em relação ao glifosato, atualmente (LOPES, 2014).

Diante disso, o bem jurídico ambiente se depara com a prevalência do interesse econômico pelo desenvolvimento. Imediatista, o ser humano tende a privilegiar os benefícios instantâneos a salvaguardar recursos de vida para depois. Logo, nesse embate com o poder econômico, fica difícil, ou mesmo, impensável, obstar a depredação ambiental somente por vias civis ou administrativas.

Destarte, o Direito Penal desponta como último e útil instrumento - ainda que subsidiário, como já fora dito anteriormente - para incrementar a segurança jurídica da coletividade com vistas a garantir a efetividade da tutela jurídica no que tange à proteção do ambiente e da qualidade de vida e à sustentabilidade.

Nesse sentido, a promulgação da Lei dos Crimes Ambientais representou um considerável avanço na tutela jurídico-penal dos delitos ambientais, pois, consolidou de forma sistêmica a legislação penal ambiental, evitando a existência das lacunas e incongruências destacadas por Luiz Regis Prado, como circunstâncias comuns das legislações fragmentárias.

\section{A LEI DOS CRIMES AMBIENTAIS: AVANÇOS E CONSIDERAÇÕES CRÍTICAS}

Além de solidificar a legislação penal ambiental quase 
completamente em uma única carta, a Lei n. 9.605/1998 trouxe novas perspectivas à tutela jurídico-penal do ambiente, como é o caso da possibilidade de aplicar cumulativamente sanções cíveis, administrativas e criminais ao agente que transgrida as normas do texto legal, tal como expressa em seu artigo $3^{\circ}$ :

As pessoas jurídicas serão responsabilizadas administrativa, civil e penalmente conforme o disposto nesta Lei, nos casos em que a infração seja cometida por decisão de seu representante legal ou contratual, ou de seu órgão colegiado, no interesse ou benefício de sua entidade. (BRASIL, 1998, p. 1).

O que mais chama atenção nesse dispositivo, muito além da possibilidade de responsabilizar os infratores cumulativamente, em diferentes esferas do direito, foi a tentativa de superação do adágio societas delinquere non potest, uma vez que o texto legal traz expressamente em seu bojo a possibilidade de responsabilização penal das pessoas jurídicas.

Vale salientar que o brocardo latino supracitado é responsável por uma grande polêmica entre os autores. De um lado, estão aqueles que defendem o princípio da intranscendência ${ }^{18}$, levantando inclusive a impossibilidade de encarcerar a pessoa jurídica ou atingi-la com as aflições da pena, as quais ela naturalmente não pode sentir.

Além disso, críticos da responsabilização da pessoa jurídica, como Luiz Regis Prado, Érika Mendes de Carvalho e Gisele Mendes de Carvalho (2014, p. 400) argumentam que as medidas administrativas são

18 Expressa no artigo $5^{\circ}$, inciso XLV, da Constituição Federal de 1988, o qual assegura que "nenhuma pena passará da pessoa do condenado". 
suficientes para inibir a ação delinquente da pessoa jurídica, enquanto o direito penal ficaria adstrito à tutela das pessoas físicas que tivessem responsabilidade sobre a ação ou omissão praticada.

Não desdenhando dos consistentes argumentos desta corrente de pensamento, existem os que defendem a possibilidade de se aplicar cumulativamente sanções penais às pessoas físicas e jurídicas ${ }^{19}$ que estejam envolvidas em delitos ambientais, sendo que a punição da pessoa jurídica recairia em penas pecuniárias, restrições de direitos e prestação de serviços comunitários, até a liquidação coercitiva da sociedade ${ }^{20}$.

Evidentemente, “é impossível conceber a responsabilização do ente moral desvinculada da ação de uma pessoa física, que atua como elemento subjetivo próprio, seja a título de dolo ou de culpa" (MILARÉ, 2004, p. 984). No entanto, também é incoerente responsabilizar exclusivamente a pessoa física, sendo que, por vezes, a ação finalista a que se dirige o delito reflete um interesse próprio do ente coletivo, que não se coincide inteiramente com a intenção pura de qualquer pessoa física a ele relacionada.

Ainda, há que se considerar que, em sua origem, "societas" não se referia à associação firmada para fins dispostos em um contrato. $\mathrm{Na}$ verdade, sociedade na época do Império Romano não tinha outro significado senão a agremiação humana natural ${ }^{21}$ dos seres humanos.

Ademais, embora haja um acirrado debate doutrinário neste

19 Anote-se a imprescindibilidade de punir a pessoa jurídica conjuntamente com as pessoas físicas que consolidaram no mundo o interesse do ente coletivo, de modo que a culpabilidade - aspecto subjetivo do delito - emana da pessoa física que praticou o ato e recai sobre a pessoa jurídica, aderindo à personalidade jurídica do ente moral, o qual por um lado serve de instrumento ao agente físico e cujo benefício representa a finalidade do injusto praticado.

20 Possibilidades estas abarcadas pela Lei dos Crimes Ambientais, em seus artigos 21 e seguintes.

21 Seja pela sobrevivência e proteção, pelo fortalecimento individual que a guarnição do grupo oferece ou pela intenção de dominação sobre outros indivíduos ou grupos, dentre tantas possibilidades de finalidade para a agremiação social, o que deve ficar patente é que a sociedade empresarial é artificial, diferente do que "societas" designava em tempos remotos. 
sentido, o artigo $3^{\circ}$ da Lei de Crimes Ambientais apenas consolidou uma determinação constitucional que padecia de regulamentação. Eis que dispõe a Lei Maior, em seu artigo 225, $\S 3^{\circ}$ :

As condutas e atividades consideradas lesivas ao meio ambiente sujeitarão os infratores, pessoas físicas ou jurídicas, a sanções penais e administrativas, independentemente da obrigação de reparar os danos. (BRASIL, 1998, p. 3). (grifo nosso).

Resta indiscutível, portanto, a legitimidade da imputação de responsabilidade penal à pessoa jurídica. Todavia, é flagrante que o legislador deixou lacunas difíceis de serem preenchidas no texto legal. Argumenta-se, com sólida fundamentação, que "a falta de critério do legislador para redação dos arts. 21 a 24 da Lei 9.605/98, que fala das penas aplicáveis à pessoa jurídica, fulminou de inconstitucionalidade as sanções previstas aos entes coletivos" (CORRÊA JÚNIOR; SHECAIRA, 2002, p. 460-461).

Destarte, pode-se afirmar que a Lei n. 9.605/98 deu um importante passo em direção à responsabilização penal da pessoa jurídica e, logo, da "solução de uma antiga querela jurídica, sobre a utilização de pessoas jurídicas como verdadeiros panos de fundo dos entes físicos" (MIGLIARI JÚNIOR, 2004, p. 191), mas ainda carece que sejam estabelecidos os nortes necessários a sua aplicação. Resta esperar que os legisladores ou a jurisprudência realizem esta tarefa.

Seguindo adiante, a Lei de Crimes Ambientais inaugura uma tutela mais holística do bem jurídico ambiental, incluindo tipos culposos e penas restritivas de direito, "o que favorece o papel dos implementadores 
da legislação ambiental (agentes ambientais, polícia, Ministério Público e Poder Judiciário)" (MILARÉ, 2004, p. 1013).

Merece destaque, também, a inclusão dos crimes de perigo, que impõem sanções penais a condutas que, independente do resultado, ofereçam risco ao ambiente, "técnica que se mostra bastante adequada com relação aos crimes ecológicos, uma vez que a proteção precípua do meio ambiente deve privilegiar a prevenção" (PADILHA, 2010, p. 300).

Disso tudo se extrai que a Lei dos Crimes Ambientais estabelece a prevalência da preservação do bem jurídico protegido sobre a reafirmação do ordenamento jurídico pela retribuição. Outro aspecto da Lei n. 9.605/98 que atesta neste mesmo sentido é a inclinação da Lei dos Crimes Ambientais a penas menos gravosas, sobretudo satisfeita a reparação do dano causado ao ambiente.

Controversa, esta posição minimalista é alvo de inúmeras críticas. Entretanto, são inumeráveis também os estudos que desvinculam a relação entre a severidade e o poder inibitório das penas. No Brasil, Sérgio Salomão Shecaira oferece reiteradas críticas ao sistema carcerário. Em obra conjunta com o magistrado Alceu Corrêa Júnior, afirmam que:

[...] não há como aceitar que a imposição da pena tenha como finalidade a retribuição do mal causado, pois a sanção deve ter um sentido construtivo, na direção da solução dos problemas sociais (...) torna-se também finalidade da pena a criação de mecanismos e condições ideais para que o delinqüente retorne ao convívio da sociedade sem traumas ou seqüelas que impeçam uma vida normal. Sem tais condições, o resultado da aplicação da pena tem sido, invariavelmente (...) o retorno à criminalidade (CORRÊA 


\section{JÚNIOR; SHECAIRA, 2002, p. 146).}

Neste diapasão, Charles-Louis de Secondatt, barão de Montesquieu, assinala que "nos países em que as penas são mais brandas, o espírito do cidadão é atingido por elas, como também o é pelas leis severas" (MONTESQUIEU, 2002, p. 96). A razão disso é que o mecanismo decisório humano não tem o condão de calcular numericamente, mas apenas logicamente, a relação de custo e benefício de suas condutas. Assim, o ser humano sopesará entre o sim e o não, dentro de uma árvore de infinitas possibilidades, não importando a razão aritmética das possibilidades.

Aliás, como sabiamente percebera o Marquês de Beccaria, "a certeza de um castigo, mesmo moderado, causará sempre a impressão mais intensa que o temor de outro mais severo, aliado à esperança de impunidade" (BECCARIA, 2005, p. 92).

Assim, os esforços de uma tutela jurídica eficaz não devem se debruçar sobre o mecanismo de aplicação das penas nem pugnar pela sua severidade, mas, antes disso, deve promover a precaução das condutas lesivas ao bem jurídico tutelado, desenvolver aparelhos hábeis a ensejar a reparação dos danos causados à sociedade e concentrar-se na fiscalização e policiamento das condutas praticadas, garantindo a efetiva contrapartida àqueles que realmente façam jus ao castigo. Nota-se que a Lei dos Crimes Ambientais vem trilhando estes caminhos, mas ainda há muito a percorrer no direito e, mormente, na seara política.

\section{A ONTOGNOSEOLOGIA APLICADA AO ESTUDO DA PENA}

De princípio é imperativo esclarecer a significação expressa pelo 
termo "ontognoseologia". Em sua origem grega, a palavra ontos ${ }^{22}$ indica o fato, a instância do ser no mundo das coisas. Ou seja, representa a própria essência das coisas, a coisa como ente. Segundo Martin Heidegger, a “compreensão do ser é compreensão ontológica. Conhecimento do ente (...) nele mesmo é conhecimento ôntico". (HEIDEGGER, 2008, p. 215). Portanto, ontologia é a disciplina que visa à compreensão do ser, da essência da res.

A expressão gnosi ${ }^{23}$, por sua vez, importa na cognoscência das coisas para o intelecto do sujeito cognoscente. Trata, em outras palavras, da esfera de conhecimento que alumia um tema, uma área ou qualquer coisa cognoscível, da possibilidade de conhecer. De fato, há que se reconhecer a impossibilidade de conhecimento absoluto do ser. Uma vez que cada indivíduo recebe as informações do mundo de uma perspectiva própria, é preciso exercer uma árdua elaboração lógica para alcançar um entendimento mais próximo da essência real do ser.

Prosseguindo esta análise, ante a luz lançada sobre o termo pelo seu estudo etimológico, infere-se que a ontognoseologia abarca o estudo $\left(\operatorname{logoi^{24}}\right.$, em grego) acerca da essência - ou a existência empírica - de um determinado objeto, direcionado pelo conhecimento havido sobre este objeto. Isto é, a ontognoseologia pretende à compreensão lógica de um determinado ente pela análise atenta de tudo que se possa saber a respeito do ente cognoscível.

Miguel Reale lecionou que a ontognoseologia constitui, lato sensu, a parte transcendental da teoria do conhecimento, aquela que cuida dos "pressupostos do ato mesmo de conhecer" (REALE, 1999, p. 27), ou seja, busca saber a partir de quais verdades fundamentais -

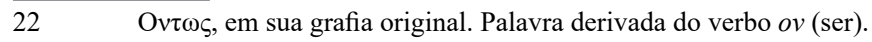

$23 \quad \Gamma v \omega \sigma \eta$, em sua grafia original.

$24 \Lambda$ oyol, em sua grafia original. 
ônticas, empíricas, e não apenas lógicas - se assenta o conhecimento acerca de um determinado tema, galgando real compreensão sobre o objeto cognoscível.

Enfim, torna-se simples a conclusão de que ontognoseologismo consiste, portanto, na corrente de pensamento que estuda seu objeto a partir da perspectiva ontognoseológica, isto é, que não prescinde, absolutamente, de uma estreita vinculação entre a natureza das coisas e os valores que the subjazem.

Consagrada por Hans Welzel, com a publicação de Studien zum System des Strafrechts (1939), a teoria finalista - ou ontognoseologismo - surge no contexto moderno pela tentativa de superar a concepção positivista, para o qual "o objeto da ciência jurídica é apenas o Direito positivo", o que fora também o intento do neokantismo que, todavia, não se desincumbiu desta tarefa (PRADO, 2008, p. 94).

Para tanto, Welzel se apoiou sobre uma complexa teia filosófica de natureza ontognoseológica, fenomenológica e axiológica (PRADO, 2008, p. 95), a fim de compreender o fenômeno penal sob todos os seus aspectos.

Considerando compreendida a abrangência do ontognoseologismo, a partir daqui é possível focalizar sob esta perspectiva o nosso objeto para, então, começar um exame mais profundo dos limites ontognoseológicos das penas aplicadas aos delitos ambientais e, em rumo a este objetivo, há que serem analisados os fins da própria pena.

A pretensão de explicar a razão existencial da pena não é contemporânea e perfará um longo caminho até chegar ao finalismo de Welzel. Ainda em meados do século XVIII, Cesare Bonesana, o marquês de Beccaria, apresentara um estudo anotando que a pena deve ser proporcional ao delito e perseguir a finalidade de "impedir que o réu 
cause novos danos aos seus concidadãos e dissuadir os outros de fazer o mesmo" (BECCARIA, 2005, p. 62).

Para Kant, por outro lado, a pena é um imperativo categórico e tem a finalidade de retribuir negativamente à atitude do criminoso. Calculista, Immanuel Kant afirma que o princípio fundamental do direito de punir reside no ius talionis ${ }^{25}$ (KANT, 2003, p. 206).

Também Georg Hegel, sucessor de Kant na corrente idealista alemã, apresentara sua teoria sobre a pena, dissertando que a existência fenomenológica e validade do direito estão condicionadas à afirmação de seus preceitos na sociedade, garantida por meio da negação das vontades particulares que se oponham a suas normas universais (HEGEL, 1997, p. 80).

Isto é, na perspectiva hegeliana, o Direito afirma sua autoridade a partir da negação de atos contrários a suas disposições, de sorte que a pena constituiria um instrumento de afirmação da justiça ${ }^{26}$. Segundo escreve Hegel:

[.. ] o crime, considerado não como produção de um mal mas como violação de um direito tem de suprimir-se (...) - A pena com que se aflige o criminoso não é apenas justa em si; justa que é, é também o ser em si da vontade do criminoso, uma maneira da sua liberdade existir, o seu direito. E é preciso acrescentar que, em relação ao próprio criminoso, constitui ela um direito, está já implicada na sua vontade existente, no seu ato. Porque vem de um ser de razão, este ato implica a universalidade que por si mesmo o criminoso reconheceu e à qual se deve submeter

25 Em latim, direito de retaliação.

26 Que para Hegel é integramente refletida na imagem do Direito. 
como ao seu próprio direito. (HEGEL, 1997, p. 89).

Pelo trecho transcrito, fica claro que Hegel entende a pena como a consequência lógica e ideal do delito e cuja função, já mencionada, é a reafirmação do Direito e da justiça. Somente em meado do século XX, na Alemanha, Hans Welzel expõe:

Ningún derecho puede imponer o prohibir algo a meros procesos de la naturaleza. Sólo en cuanto alcancen el poder finalista de creación de las acciones humanas sobre los acontecimientos de la naturaleza, el derecho puede imponer o prohibir algo a las acciones. (WELZEL, 1956, p. 8).

Isto é, o poder de controle do direito tem sua envergadura restrita às ações humanas, sendo necessário alcançar - pela influência positiva ou negativa ${ }^{27}$ - o âmago das ações humanas, na finalidade de sua intenção.

Aliás, não haveria como ser diferente, haja vista a origem linguística dos preceitos jurídicos e sua natureza lógico-interpretativa. Logo, é devido a sua natureza linguística e à sua autoridade selada pela força estatal que a lógica jurídica de ação-imputação possui aptidão para influenciar a tomada de decisões e, com isso, condicionar o direcionamento das ações humanas.

Dentre tudo o que se entende pela real finalidade da aplicação penal, pode-se destacar o entendimento

[...] a pena se justifica pela sua utilidade social, 
isto é, pela sua funcionalidade para o sistema, e o Direito Penal é um mecanismo de controle social que se vale das penas e das medidas de segurança para estabilizar a vigência da norma (CARVALHO 2008, p. 42).

Perfilhando este pensamento, pode-se concluir que a Lei dos Crimes Ambientais atende a uma utilidade social máxima, qual seja a coerção da sociedade à preservação do ambiente ${ }^{28} \mathrm{e}$, subsidiariamente, busca solidificar a validade da norma jurídico-penal-ambiental e do próprio ordenamento jurídico, por meio de uma tentativa de reafirmação jurídica com o emprego da pena e de seus efeitos simbólicos.

\section{A INFLUÊNCIA DO ONTOGNOSEOLOGISMO NO DIREITO PENAL AMBIENTAL BRASILEIRO}

Observando as inovações trazidas pela Lei n. 9.605/98 fica evidente sobre quais pontos incidira mais diretamente a influência do pensamento finalista e, por outro lado, em quais aspectos houve algum tipo de discordância.

Uma relevante inovação da Lei dos Crimes Ambientais foi incluir a tipificação de delitos culposos contra o meio ambiente. Eis que grande parte das críticas ao finalismo recai exatamente sobre a questão da ação finalística nos crimes culposos. Enquanto "no delito doloso, é punida a ação ou a omissão dirigida a um fim ilícito ${ }^{29}$; (...) no culposo, pune-se o comportamento mal dirigido a um fim irrelevante (ou lícito)" (PRADO, 2008, p. 328). Ou seja, nos crimes culposos a punição não visa inibir a

28 Em todos os seus aspectos, desde o preventivo, inibitório, ao reparador.

29 Grifo no original. 
vontade consciente de atingir um objetivo ilícito, mas obrigar a adoção de postura cautelosa diante dos bens jurídicos de relevante valor social ${ }^{30}$.

Nesse sentido, depreende-se que ao incluir tipos culposos contra o ambiente, a Lei dos Crimes Ambientais teve vistas à proteção do ambiente não somente contra a conduta finalista em si, mas também contra atos de imprudência, negligência ou imperícia, exigindo a postura finalista de evitar o dano ambiental.

Outra importante consideração - embora não represente nenhuma novidade no ordenamento jurídico brasileiro, já tendo sido aproveitado no Código Penal de 1940 - é o emprego da culpabilidade para aferir a gravidade que ensejará a reprovabilidade da decisão de vontade, visando à proporcionalidade da pena. Assim dispõe a Lei 9.605, de 1998 , em seu artigo $2^{\circ}$ :

Quem, de qualquer forma, concorre para a prática dos crimes previstos nesta Lei, incide nas penas a estes cominadas, na medida de sua culpabilidade, bem como o diretor, o administrador, o membro de conselho e de órgão técnico, o auditor, o gerente, o preposto ou mandatário de pessoa jurídica, que, sabendo da conduta criminosa de outrem, deixar de impedir a sua prática, quando podia agir para evitá-la. (BRASIL, 1998, p. 1)

Também se extrai do excerto acima a intenção do legislador em inibir a prática de crimes ambientais no setor industrial, bem como evitar a corrupção dos agentes públicos encarregados da fiscalização. Nessa direção destaca-se a tentativa da inserção da pessoa jurídica no rol de 
sujeitos penalmente imputáveis pelos delitos previstos no texto da Lei.

Quanto a esta peculiaridade, tradicionalmente a corrente ontognoseológica se posiciona contrariamente à possibilidade de delinquência pela pessoa jurídica, assinalando que a pessoa jurídica é uma figura fictícia e não tem capacidade de ação ou omissão para desempenhar uma atividade finalista (PRADO, 2008, p. 421).

Nessa perspectiva, tem-se que, em grande parte, os delitos ambientais são praticados com fins à manutenção de uma atividade capitalista e, destarte, seus maiores beneficiários são exatamente as pessoas físicas que se escondem sob o manto das jurídicas.

Assim sendo e considerando que o ambiente, em contínuo processo de degeneração, padece de uma carência cada vez maior diante das condições contemporâneas, é flagrante que a responsabilização penal da pessoa jurídica é medida que soa como uma forma de embuste na tentativa de constranger à preservação ambiental.

Por fim, se tem a possibilidade de extinção da punibilidade pela reparação do dano ambiental, o que caminha de encontro com uma tendência muito positiva em direção à aplicação de penas alternativas e busca de sanções mais adequadas a cada caso, especialmente os menos gravosos.

Com isso, além de incentivar a reparação do dano causado, o que por si só é uma iniciativa louvável, a Lei dos Crimes Ambientais alcança uma proporcionalidade muito mais efetiva entre a pena a ser cominada e a conduta finalista praticada.

\section{POSICIONAMENTO CRÍTICO E PROPOSTA DE ADEQUAÇÃO}

Nos termos da legislação penal ambiental atual a reparação ou 
compensação do dano constitui uma medida alternativa para os crimes ambientais culposos e para aqueles de menor potencial ofensivo cujo sujeito ativo não seja reincidente, conforme prevê o artigo 28 , inciso I, da Lei n. 9.605/98.

Ademais, o Código Penal traz, em seu artigo 23, uma lista de causas justificantes, segundo a qual é lícito agir em legítima defesa, em estado de necessidade, por exercício regular de direito ou em estrito cumprimento do dever legal. Isto significa que ainda que a ação praticada seja típica, não se configura o delito, pois ausente a ilicitude.

Nesse sentido, propugna-se uma visão extensiva da excludente de ilicitude do estado de necessidade (artigo 23, inciso I, do Código Penal), na qual o Estado seja responsável pelo provimento de alternativas eficazes $^{31}$ de subsistência ao setor marginalizado da sociedade.

Por essa perspectiva, o direito do Estado de exigir uma determinada conduta do sujeito estaria condicionado à criação de mecanismos que ofereçam alternativas reais para o indivíduo. Uma vez que o Estado deixe de criar vias alternativas a um determinado fato típico, ter-se-ia que o sujeito agiu pela única via possível e, por conseguinte, torna-se inexigível uma conduta diversa.

$\mathrm{Na}$ seara do direito penal ambiental, pode-se vislumbrar o exemplo de um pescador profissional ${ }^{32}$ que viole a lei penal por estrita necessidade de manutenção própria ou familiar. Imaginemos também que a família deste pescador seja numerosa o suficiente para desconsiderar o princípio da insignificância.

Em vista do estado de necessidade, esse pescador somente

310 que poderia a princípio se buscar pela reforma da assistência social e, a longo prazo, pela consolidação de um sistema educacional acessível, democrático e eficiente.

32Que embora não esteja autorizado a violar a lei ambiental, encontra amparo para exercer livremente seu ofício, no artigo $5^{\circ}$, inciso XIII, da Constituição Federal de 1988. 
deverá se sujeitar ao ius puniendi do Estado a partir do momento que existam meios lícitos alternativos ${ }^{33}$ para garantir à satisfação da finalidade do ato ilícito - no caso, a manutenção familiar e própria.

A este respeito, destaca Hannah Arendt que "nenhuma violência exercida pelo homem exceto aquela empregada na tortura, pode igualar a força natural com que as necessidades da vida compelem o homem" (ARENDT, 2009, p. 141). Assim, para atingir o cerne da ação finalista, é imprescindível conhecer a origem dos impulsos e necessidades concretas do agente.

Com isso, será possível conhecer quais medidas terão poder de fato para coagir o sujeito e interferir na disposição delituosa, será possível aferir com maior precisão a torpeza de uma conduta mercenária ou a dignidade humana porventura impressa na necessidade e, ainda, a partir disso, determinar a reprovabilidade pelo injusto e a exigibilidade de conduta diversa, conforme o caso concreto e não conforme o homem médio.

Portanto, em conformidade com Hannah Arendt, é admissível concluir que a conduta diversa - aferida da relação concreta entre o agente infrator e a sua realidade particular - não pode ser exigida do sujeito cuja ação lhe seja a única via de atendimento às necessidades da vida.

Entretanto, isso somente se aplicaria à baixa delinquência. Não se olvide que a modernidade, marcada pela Globalização dos mercados e das culturas, bem como, pela capacidade incomparável de coordenação, manipulação, estruturalizante dos empreendedores apresenta uma criminalidade diversa, econômica e bastante influente, capaz de se postar ao lado - ou, dentro, até mesmo - do próprio Estado.

33 Como, por exemplo, um fundo de amparo ao trabalhador rurícola, enquadrando-se nesta classe de trabalhador todo aquele que retire seu sustento da extração para consumo próprio ou revenda de recursos naturais, sem submetê-los a processos industriais que modifiquem sua natureza, o que os tornaria artificiais. 
Trata-se da criminalidade dos poderosos, ou, da delinqüência econômica especializada que, na área ambiental, pode ser definida como criminosos do colarinho verde, numa analogia à obra de Sutherland (2015).

Se o ambiente merece proteção e se o Direito Penal pretende ser a ultima ratio nessa tarefa, não pode simplesmente ignorar as idiossincrasias que lhe são próprias e terá de se desnudar da roupagem clássica e revestir-se de uma forma moderna que, respeitando as bases epistemológicas de sua formação, ainda assim, possa buscar conferir alguma proteção a esse bem jurídico com tantas especialidades, principalmente, sua difusidade.

\section{CONCLUSÕES}

$\mathrm{Na}$ onda global do neoliberalismo, o propósito dos Estados é impulsionar o desenvolvimento econômico, atualmente fundado na exportação de commodities, razão pela qual os limites das infrações estão sendo alargados, de modo a permitir maior exploração dos recursos naturais pela ordem econômica.

Obviamente, nesse processo, toda e qualquer forma ou tentativa de se impor limites à exploração econômico-industrializante é vista como um modelo desinteressante pelo sistema e cadeia produtivos. Vista como óbice, a tutela jurídico-penal do ambiente padece do mesmo problema enfrentado pelo Direito Penal contemporâneo, isto é, como atualizar-se para a modernização.

Como subsistir enquanto um dos instrumentos de controle social que necessita, justamente, enfrentar a criminalidade dos poderosos, pois, em sua origem, foi criada para o oposto?

Nesse impasse, revela-se imperativo que as massas se 
movimentem ativamente, a fim de pressionar o Estado para que proteja efetivamente o bem jurídico ambiente em face dos interesses econômicosindustrializantes, lutando para que os limites jurídicos sejam realmente calcados na dialética entre a ação finalista e o dano causado para que se estabeleça uma pena justa e cuja finalidade seja revestida de interesse social, ou seja, primando pela introdução e manutenção do espectro capitalista no seio do Direito Penal Ambiental, como forma de limitá-lo.

Ademais, somente será possível estabelecer formas de punição a partir da observação da reprovabilidade do injusto praticado em face dos impulsos finalistas que levaram o sujeito àquela conduta, não sendo defensável, neste trabalho, a ideia de se assegurar uma zona de conforto ou de isenção penal para a delinqüência do colarinho verde.

Enquanto perdurarem os valores da racionalidade econômica em detrimento da dignidade humana não será possível constituir uma jurisdição penal ambiental justa e efetiva e a única via para mudar esses valores é a luta pela preservação do bem jurídico e pela reafirmação do direito, criando-se uma tradição de consciência ambiental que perpetue essa luta, mantendo seus ideais sempre vivos no seio da sociedade.

\section{REFERÊNCIAS}

ARENDT, Hannah. A condição humana. Trad. Roberto Raposo. 10.ed. Rio de Janeiro: Forense Universitária, 2009.

BECCARIA, Cesare. Dos delitos e das penas. Trad. de Lucia Guidicini e Alessandro Berti Contessa. 3. ed. São Paulo: Martins Fontes, 2005.

BRASIL. Constituição da República Federativa do Brasil. Brasília, DF., 1988. Disponível em: < http://www.planalto.gov.br/ccivil_03/ constituicao/constituicaocompilado.htm>. Acesso em: 07 jul. 2015. 
BRASIL. Lei N. ${ }^{\circ}$ 9.605, de 12 de fevereiro de 1998. Dispõe sobre as sanções penais e administrativas derivadas de condutas e atividades lesivas ao meio ambiente, e dá outras providências. Código Civil, Brasília, DF, 12 fev. 1998. Disponível em: <http://www.planalto.gov. br/ccivil_03/leis/L9605.htm>. Acesso em: 11 jul. 2015.

CINTRA, Antônio Carlos de Araújo; GRINOVER, Ada Pellegrini; DINAMARCO, Cândido Rangel. Teoria geral do processo. 22. ed. São Paulo: Malheiros, 2006.

CORRÊA JUNIOR, Alceu; SHECAIRA, Sérgio Salomão. Teoria da pena: finalidades, direito positivo, jurisprudência e outros estudos da ciência criminal. São Paulo: RT, 2002.

DARWIN, Charles. A origem das espécies. Trad. de André Campos Mesquita. São Paulo: Escala, 2008. Tomo I.

HEGEL, Georg Wilhelm Friedrich. Princípios da filosofia do direito. Trad. de Orlando Vitorino. São Paulo: Martins Fontes, 1997.

HEIDEGGER, Martin. Introdução à filosofia. Trad. Marco Antonio Casanova. São Paulo: Martins Fontes, 2008.

KANT, Immanuel. A metafísica dos costumes. Trad. Edson Bini. Bauru, SP: EDIPRO, 2003.

LOPES, Cláudio Ribeiro. As práxis de política ambiental e sua funcionalidade ante às vinculações ao capital industrial na região de Três Lagoas/MS e as várias disfuncionalidades delas decorrentes. Anais do V Congresso da ABraSD, 2014, p. 221-230.

MIGLIARI JÚNIOR, Arthur. Crimes ambientais: Lei no 9.605/98, novas disposições gerais penais. 2. ed. Campinas: CS Edições Ltda, 2004. 
MILARÉ, Édis. et al. Direito do ambiente: a gestão ambiental em foco. 6.ed. rev. e atual. e ampl. São Paulo: RT, 2009.

MONTESQUIEU, Charles de. Do espírito das leis. Trad. Jean Melville. São Paulo: Martin Claret, 2002.

PADILHA, Norma Sueli. Fundamentos constitucionais do direito ambiental brasileiro. Rio de Janeiro: Elsevier, 2010.

PRADO, Luiz Regis; CARVALHO, Érika Mendes de; CARVALHO, Gisele Mendes de. Curso de direito penal brasileiro. 13.ed. São Paulo: RT, 2014.

8.ed. São Paulo: RT, 2008.

. Curso de direito penal brasileiro: parte geral. v.1. . Direito penal ambiental: problemas fundamentais.

São Paulo: RT, 1992.

REALE, Miguel. Filosofia do Direito. 19. ed. São Paulo: Saraiva, 1999.

SHECAIRA, Sergio Salomão; CORRÊA JUNIOR, Alceu. Teoria da pena. São Paulo: Revista dos Tribunais, 2006.

SUTHERLAND, Edwin H. Crime de colarinho branco: versão sem cortes. Trad. Clécio Lemos. 1. ed. Rio de Janeiro: Revan, 2015.

WELZEL, Hans. Derecho penal: parte general. Trad. Carlos Fontán Balestra. Buenos Aires: Roque Depalma, 1956.

Como citar: LOPES, Cláudio Ribeiro. FACCHIN, Kleber Henrique. Limites ontognoseológicos para a tutela jurídico-penal do ambiente no 
Brasil. Revista do Direito Público, Londrina, v. 11, n. 2, p.260-288, ago. 2016. DOI: 10.5433/1980-511X.2016v11n2p260. ISSN: 1980-511X.

Submetido em 11/08/2015

Aprovado em 02/06/2016 